\title{
A starfish bed in the Middle Miocene Grand Bay Formation of Carriacou, The Grenadines (West Indies)
}

\author{
JOHN W. M. JAGT*, BEN THUY†, STEPHEN K. DONOVAN $§ \S$, SABINE STÖHR \\ ROGER W. PORTELL\|, RON K. PICKERILL\#, DAVID A. T. HARPER**, \\ WILLIAM LINDSAY †† \& TREVOR A. JACKSON $\ddagger$ \\ *Natuurhistorisch Museum Maastricht, de Bosquetplein 6-7, NL-6211 KJ Maastricht, The Netherlands \\ †Geoscience Centre, University of Göttingen, Department of Geobiology, Goldschmidtsrasse 3, \\ D-37077 Göttingen, Germany \\ $\ddagger$ Naturalis Biodiversity Center, P.O. Box 9517, NL-2300 RA Leiden, The Netherlands \\ TSwedish Museum of Natural History, Department of Zoology, Box 50007, SE-10405 Stockholm, Sweden \\ ||Florida Museum of Natural History, University of Florida, Gainesville, Florida 32611, USA \\ \#Department of Geology, University of New Brunswick, Fredericton, New Brunswick, Canada E3B 5A3 \\ ** Department of Earth Sciences, Durham University, South Road, Durham DH1 3LE, UK \\ $\dagger † 9,8$ Maritime Street, Leith, Edinburgh, EH6 6SB, UK \\ $\ddagger \ddagger$ Seismic Research Centre, University of the West Indies, St Augustine, Trinidad
}

(Received 10 December 2012; accepted 13 February 2013; first published online 28 June 2013)

\begin{abstract}
The first starfish bed to be recognized from the Antilles is a lensoid body in the middle Miocene Grand Bay Formation of Carriacou, The Grenadines (West Indies). This unit was deposited in a turbidite basin in a region of active volcanism fed from one centre and preserves common deep-water taxa more typical of the Palaeozoic, such as crinoids and brachiopods. The starfish bed is a channel-fill deposit laid down in at least 150-200 m water depth, although the specimens may have been derived from shallower water. A goniasterid asteroid and an ophiacanthid ophiuroid have been recognized. The first articulated asteroid from the Antillean fossil record is Paragonaster(?) haldixoni sp. nov. In all skeletal features it appears close to the extant Atlantic species Paragonaster grandis H. L. Clark and $P$. subtilis (Perrier), but differs in having a single row of rectangular abactinal ossicles extending to the arm tip; these are longer than wide. The brittlestar, Ophiocamax ventosa sp. nov., is described on the basis of a fragmentary disc and arms from this deposit. The closest similarities are with the extant tropical western Atlantic species Ophiocamax hystrix Lyman and O. austera Verrill. However, the new species has thorns covering the entire surface of dorsal arm plates, while arm spines have a multitude of small thorns, loosely arranged in numerous rows and dorsal arm plate shape differs markedly. The occurrence of $O$. ventosa sp. nov. suggests that Ophiocamax has been a deep-sea taxon at least since the Miocene.
\end{abstract}

Keywords: Asteroidea, Goniasteridae, Ophiuroidea, Ophiocanthidae, deep water.

\section{Introduction}

Until recently, the fossil record of asterozoans (asteroids or starfishes, and ophiuroids or brittle and basket stars) in the Antillean region consisted solely of disarticulated plates or ossicles (Donovan, 2001), unlike certain adjacent regions where well-documented complete specimens are locally common (e.g. Jones \& Portell, 1988; Oyen \& Portell, 2001; Blake \& Portell, 2009, 2011). Asteroid and ophiuroid ossicles are widely distributed in the Upper Cretaceous and Cenozoic of the Antilles; they deserve further study, but have received little attention by systematists. In general, the echinoderm endoskeleton rapidly disarticulates into its component ossicles after death. As a result, articulated asterozoan skeletons are exceptional fossils as they require rapid and effective post-mortem burial to preserve the ossicles in place (Ausich, 2001).

§Author for correspondence: Steve.Donovan@naturalis.nl
Dissociated asterozoan plates may occur abundantly as microfossils, but only very few palaeontologists are expert in the systematics of these plates. Despite being diverse in the extant, shallow- and deep-water faunas (e.g. Hendler et al. 1995 and Lyman, 1883, respectively), Antillean fossil asteroids and ophiuroids therefore remain essentially unknown and have almost exclusively been recorded in open nomenclature, when noted at all. The first 'starfish bed' to be recognized from the region is therefore significant. Its interpretation as a deep-water occurrence of asterozoans has important implications for our understanding of the taphonomy and evolution of Antillean echinoderms. From this deposit, new species of nominal fossil asteroid and ophiuroid are described.

The specimens described herein are deposited in the Naturalis Biodiversity Center, Leiden (NBC RGM) and the Florida Museum of Natural History, Gainesville (UF). 
Table 1. The fossil record of Cenozoic ophiuroids in the Antillean region.

\begin{tabular}{llll}
\hline Age & \multicolumn{1}{c}{ Location; horizon } & \multicolumn{1}{c}{ Identity } & Reference \\
\hline Late Pleistocene & Jamaica; Falmouth Formation & ophiuroid vertebrae & Donovan et al. (1993) \\
Late Pliocene & Jamaica; Bowden shell bed & gorgonocephalid or hemieuryalid vertebrae & Donovan \& Paul (1998) \\
Late Pliocene & Trinidad; Matura Formation & Ophioderma sp. vertebrae & Berry (1935) \\
Middle Miocene & Carriacou; Grand Bay Formation & Ophiocamax ventosa sp. nov. & present paper \\
Early Miocene & Jamaica; Montpelier Formation & Ophiomusium? sp. vertebrae & Donovan et al. (2005) \\
Oligo-Miocene & Puerto Rico; unnamed formation & articulated ophiuroids & Vélez-Juarbe \& Santos (2008) \\
Late Oligocene & Jamaica; Moneague Formation & ophiuroid vertebrae & Dixon et al. (1994) \\
Late Oligocene & Puerto Rico; Lares Limestone & articulated ophiuroids & Vélez-Juarbe \& Santos (2008) \\
\hline
\end{tabular}

\section{History of research}

Echinoids are the only common and well-documented echinoderm fossils in the Mesozoic and Cenozoic of the Antillean region. Although disarticulated ossicles of asteroids, ophiuroids and crinoids do occur, they are uncommon, are rarely recognized by palaeontologists in the field and have received little attention in the scientific literature (Donovan, 2001). Despite being the most diverse group of echinoderms in modern shallowwater environments of the Caribbean (Hendler et al. 1995, pp. 89-195), ophiuroids (Table 1) and asteroids (Donovan \& Schelfhorst, 2012, table 1) are almost unknown as fossils from the Antilles. The only other articulated specimens hitherto reported are from the Oligo-Miocene of Puerto Rico (Vélez-Juarbe \& Santos, 2008); these have not yet been formally classified and described.

Our limited knowledge of the distribution of fossil asteroids and ophiuroids is undoubtedly highly biased, particularly towards Jamaica, where one of us (SKD) and his research students have been collecting fragmentary echinoderms since 1986. Known occurrences of asteroid and ophiuroid ossicles in Jamaica are from units in which considerable research effort was expended in collecting echinoderms; these are not the Upper Cretaceous and Eocene formations that yielded most of the fossil echinoids from Jamaica in the 1920s and 1930s (Hawkins, 1923, 1924, 1927, 1930; Arnold \& Clark, 1927, 1934; Donovan, 1988, 1993), particularly the Lower-Middle Eocene Yellow Limestone Group. We therefore have the paradoxical situation that no ophiuroid ossicles are known from the unit that has yielded the greatest diversity of fossil echinoderms in Jamaica, although asteroid marginal plates have been recorded (Donovan, 2001, table 5).

That asterozoans remain almost unknown in the Antilles has an obvious taphonomic explanation. Ophiuroids and asteroids generally have a low preservation potential and disarticulate rapidly upon death (e.g. Blake, 1989; Donovan, 1991). Unlike other echinoderm groups which have some ossicles that are large and obvious to the naked eye, such as cidaroid spines, isocrinid columnals and goniasterid marginal plates, even the largest ophiuroid ossicles, that is, vertebrae, lateral arm plates and radial shields of the disc, can only be recognized by micropalaeontological analysis of poorly lithified sedimentary rock. The same is true for the majority of the diagnostic plates of asteroids.
A micropalaeontologist will likely not be interested in echinoderm fragments and most echinoderm workers concentrate their collecting effort on macrofossils. The macroscopic specimens described here are not just the first Antillean fossil ophiuroid and asteroid to be named, but the first Antillean fossil ophiuroid and asteroids that were easy to find.

\section{Locality and horizon}

The specimens described below come from a channelfill-sandstone in the Middle Miocene Grand Bay Formation exposed on the east coast of Carriacou, The Grenadines, Lesser Antilles (Fig. 1). The following account is adapted from Donovan et al. (2003). The Middle Miocene Grand Bay Formation is comprised principally of beige to light brown, fine- to coarsegrained volcaniclastic sandstones with intercalated horizontally and finely laminated to massive silty and sandy mudstones and calcareous mudstones, and associated with sporadically developed volcanogenic pebbly sandstones and conglomerates. The strata are abundantly fossiliferous, dominated by diverse assemblages of molluscs, but also including, among other taxa, scleractinian corals, brachiopods, echinoids, crinoids, decapod crustaceans, barnacles, algae and vertebrates (Donovan et al. 2003).

Brief descriptions and palaeoenvironmental interpretations of the strata were presented by Jung (1971) and Speed et al. (1993), who differed radically in their conclusions. Based on comparison with extant molluscan and scleractinian coral faunas, Jung (1971, pp. 158-60) concluded that the Grand Bay Formation was a relatively deep-water sequence. In contrast, Speed et al. (1993, p. 55) speculated that it was a shallow-water succession. Donovan \& Harper (1999, 2001), based on the occurrence of stalked crinoids, brachiopods and the ichnofossil Zoophycos, and Donovan et al. (2003), referring to the data supplied by sedimentology, ichnology and a wider set of palaeontological observations, emphatically supported Jung's conclusion. Sedimentological evidence suggests that the Grand Bay Formation was deposited in relatively deep water, and certainly below fair weather and storm wave base, as the strata do not contain any evidence of wave activity. In addition, the presence of channels and slump horizons in the essentially turbiditic sequence suggests penecontemporaneous erosion and the presence of 


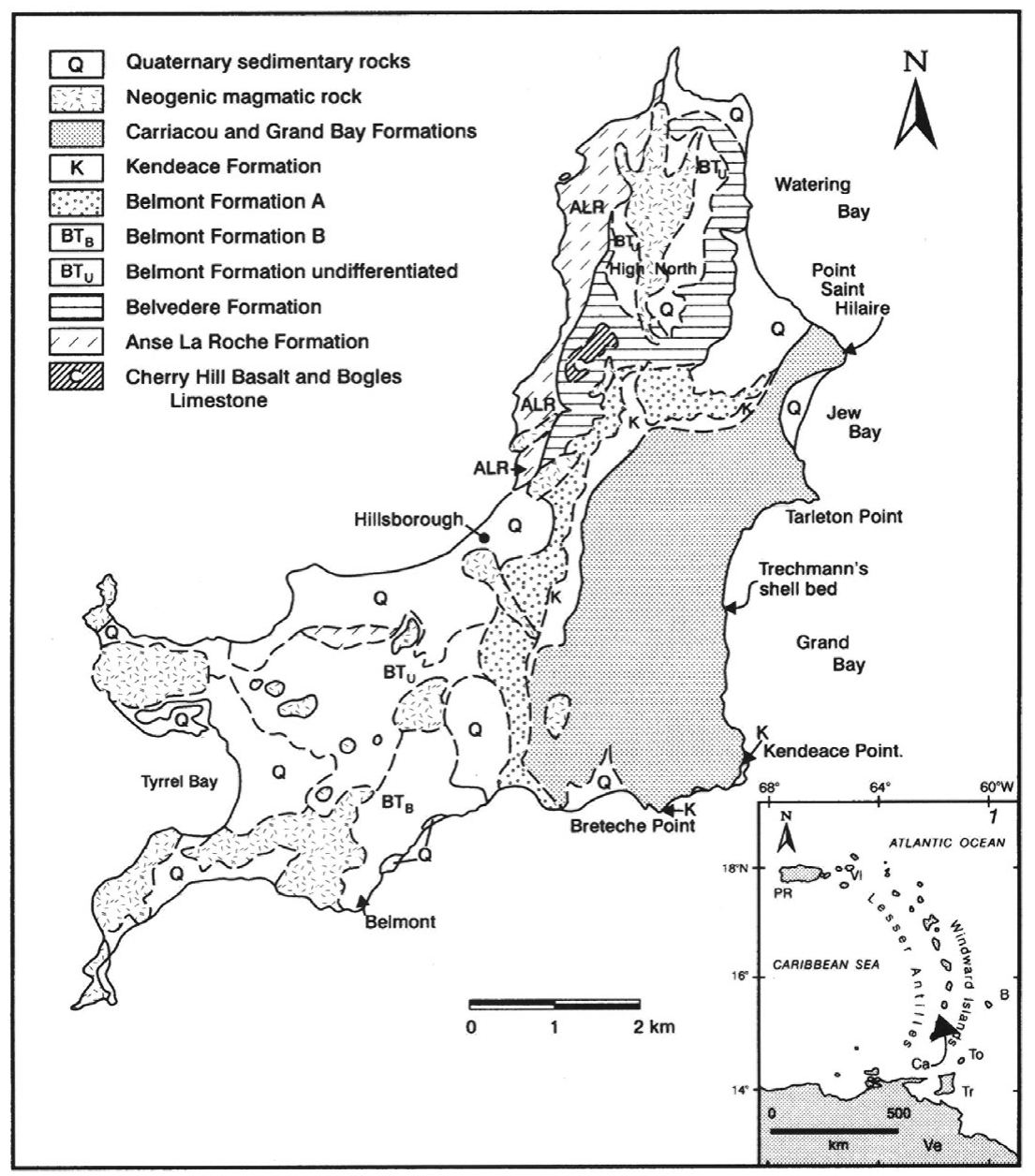

Figure 1. Simplified geological map of Carriacou, after Donovan et al. (2003, fig. 1), and modified after Speed et al. (1993, fig. 7) and T.A. Jackson (unpub. M.Sc. thesis, University of West Indies, 1970, map), showing principal localities mentioned in text. The starfish bed is at the south end of Jew Bay, north of Tarleton Point and beneath the Quaternary cover. Inset map of Lesser Antillean region shows the position of Carriacou (arrowed). Key: $\mathrm{B}=$ Barbados; $\mathrm{Ca}=$ Carriacou; $\mathrm{PR}=$ Puerto Rico; To $=\mathrm{Tobago}$; $\mathrm{Tr}=\mathrm{Trinidad}$; $\mathrm{Ve}=$ Venezuela; $\mathrm{VI}=$ Virgin Islands.

some form of slope. Based on various lines of evidence, the depth of deposition was at least 150-200 $\mathrm{m}$ (Jung, 1971; Donovan \& Harper, 1999, 2001; Donovan et al. 2003) and probably deeper (Donovan, 2012). At this water depth taxa typically found in modern bathyal settings, such as articulated brachiopods and stalked crinoids (Donovan \& Veltkamp, 2001), thrived in the Caribbean and continue to do so.

Recently published geochemical analyses have demonstrated a single source for the various volcanic grains incorporated in this turbiditic deposit (Jackson et al. 2008), but the volcanic centre from which it originated remains unknown. This combination of turbidite basin deposition in a region of active volcanism led to the formation of a rare sedimentary deposit: a starfish bed. This starfish bed is the only one known from the Antilles and the sole deposit in the region to yield both an articulated asteroid (Figs 2,3) and an articulated ophiuroid (Figs 4-6) although, admittedly, both specimens are incomplete.

The starfish bed is to the north of Tarleton Point in Jew Bay (Fig. 1), to the north of the stream and in the area of Jung's (1971) localities 10706-10723
(GPS $12^{\circ} 29^{\prime} 25^{\prime \prime} \mathrm{N}, 61^{\circ} 25^{\prime} 30^{\prime \prime} \mathrm{W}$ ). This horizon is exposed beneath the angular unconformity with the overlying Quaternary Carriacou root beds (Donovan et al. 2002). The fossil asterozoans are higher in the succession than the measured section of Harper \& Pickerill (2008, fig. 2). Although grant support was forthcoming to support further research of this deposit, problems of access prevented our return.

\section{Systematic palaeontology}

Class ASTEROIDEA de Blainville, 1830 Subclass NEOASTEROIDEA Gale, 1987 Order VALVATIDA Perrier, 1884

Family GONIASTERIDAE Forbes, 1841 Genus Paragonaster Sladen, 1885

Type species. Paragonaster ctenipes Sladen, 1889, by subsequent designation of Fisher (1919).

Diagnosis. Goniasterid with stellate body form; abactinal ossicles paxilliform, covered with rounded 


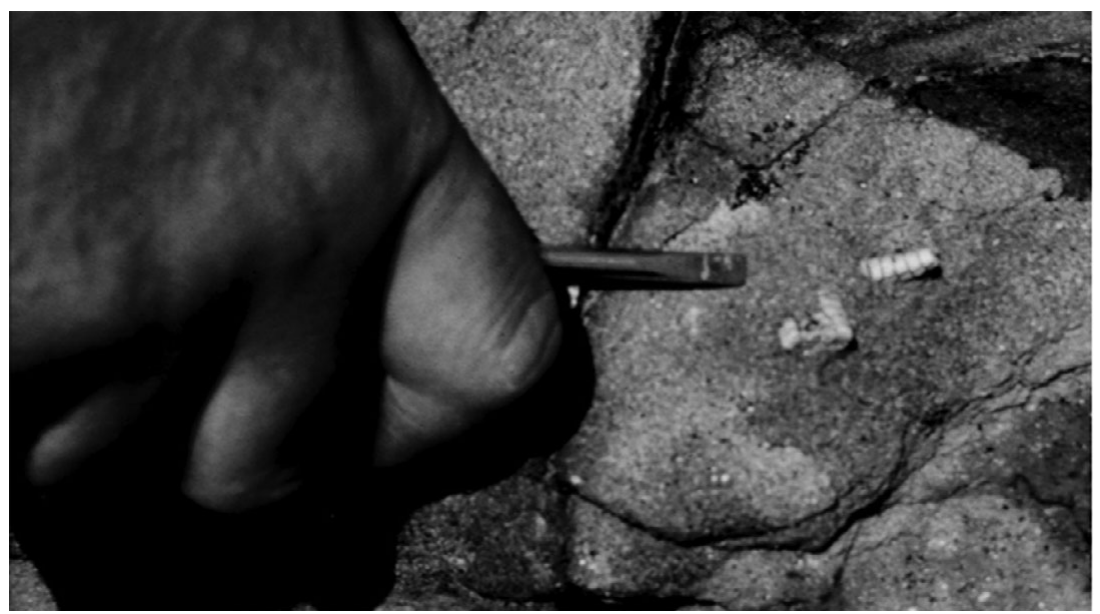

Figure 2. In situ asteroid, Paragonaster(?) haldixoni sp. nov., UF 114750, holotype, in the Middle Miocene starfish bed of the Grand Bay Formation of Carriacou.

granules; one median row of abactinals extending to terminal, usually somewhat rectangular in shape and wider than long; adambulacral furrow margin angular; apical oral spine unpaired; no pedicellariae (modified from Clark \& Downey, 1992, p. 255).

Range. Middle Miocene (the present record) to Recent (Clark \& Downey, 1992).

\section{Paragonaster(?) haldixoni sp. nov.} Figures 2, 3

\section{?2001 unidentified marginal ossicles; Donovan, table 5. \\ 2003 Astropecten sp. nov.; Donovan et al. p. 264. 2008 a goniasterid asteroid; Donovan et al. p. 52. \\ $2008 b$ goniasterid asteroid; Donovan et al. p. 18.}

Etymology. For our late colleague and co-author, Harold L. 'Hal' Dixon, formerly of the Department of Geology, University of the West Indies, Mona, in recognition of his contribution to Caribbean invertebrate palaeontology.

Holotype. UF 114750 , the only specimen known.

Related material. Disarticulated asteroid marginal ossicles occur rarely in the basal part of the Grand Bay Formation, in association with crinoid ossicles (Donovan \& Veltkamp, 2001), and at other horizons in this unit (NBC RGM 188797 and 188 798). Larger collections are required before it is possible to determine if they are conspecific with the present taxon. The type locality of Paragonaster(?) haldixoni sp. nov. has yielded two other asteroid specimens belonging to different species; one of these disintegrated soon after it was collected and the other represents a fragment of a spinose arm (NBC RGM 188 799).
Type locality and horizon. A channel-fill sandstone in the Grand Bay Formation (Middle Miocene) on the east coast of Carriacou, The Grenadines, Lesser Antilles. The locality is to the north of Tarleton Point in Jew Bay (Fig. 1), to the north of the stream and in the area of Jung

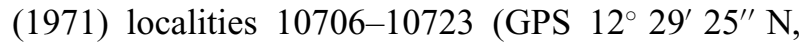
$\left.61^{\circ} 25^{\prime} 30^{\prime \prime} \mathrm{W}\right)$. The ophiuroid/asteroid-bearing bed is exposed beneath the angular unconformity with the overlying Quaternary Carriacou root beds (see above).

Preparation. The specimen was collected in two main pieces, broken through the proximal area of one arm, with some separated ossicles. The two large parts were joined with a viscous solution of Paraloid B72 (a copolymer of ethyl methacrylate and methyl acrylate in acetone) after the joint surfaces were consolidated with Paraloid B72 diluted in butan-2-one. Ossicles were reattached to the ends of one arm.

Most of the asteroid was enclosed in the matrix, which consisted of fine-grained sandstone with granular fragments, but the distal ends of the arms were already visible. The matrix was soft enough to remove with a hand-held tungsten carbide needle, but responded more readily to preparation using an airbrasive (Texas Airsonics HP series) with 50 microns grade sodium bicarbonate powder. Powder flow and air pressure were adjusted to avoid damage to the fossil calcite. Preparation commenced on the apical side and this surface was wholly exposed before the oral surface was addressed. The matrix was completely removed from one of the interradial areas, but left attached on other margins to allow handling and to support the adhesive joint. A dilute solution of Paraloid B72 in butan-2-one was applied to the exposed fossil surface to cement the ossicles in place.

Diagnosis. Medium-sized goniasterid of stellate, flat form; arms long, slender and pointed; abactinal ossicles paxilliform; single row of abactinals, longer than wide, extending to arm tip; $R / r=>3.2 / 1$; uniform 


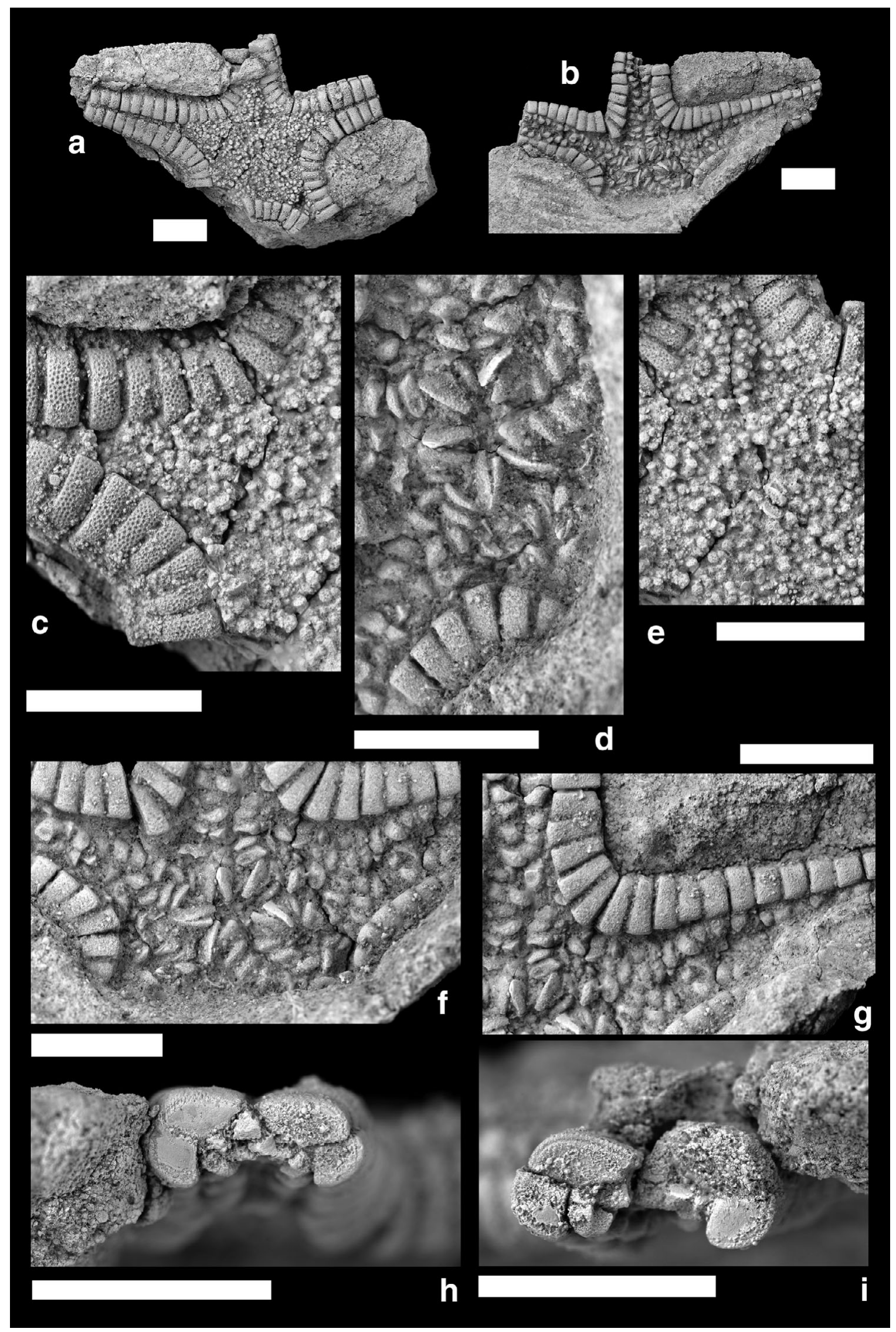

Figure 3. Paragonaster(?) haldixoni sp. nov., UF 114750, holotype, Middle Miocene starfish bed, Carriacou, The Grenadines. (a) Abactinal (dorsal) surface. (b) Actinal (oral) surface. (c, e) Details of marginal frame and abactinal plating, respectively. (d, f, g) Details of the mouth frame, actinal plating and marginal frame, respectively. (h, i) Arms in section. Specimen coated with ammonium chloride. All scale bars represent $10 \mathrm{~mm}$. 


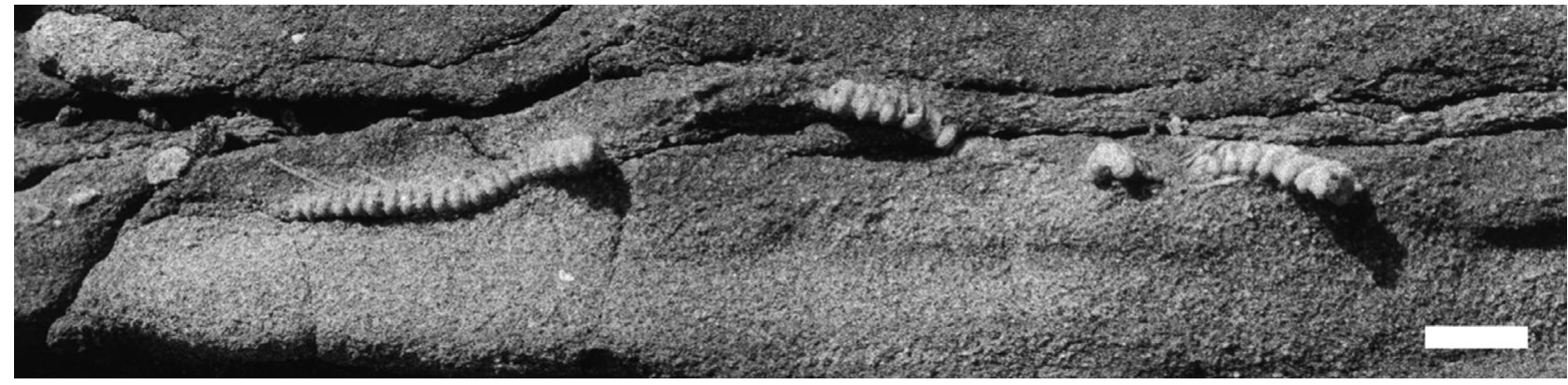

Figure 4. In situ ophiuroid, Ophiocamax ventosa sp. nov., NBC RGM 791 150, holotype, in the Middle Miocene starfish bed of the Grand Bay Formation of Carriacou. Scale bar represents $10 \mathrm{~mm}$.

granulation on superomarginals and inferomarginals; large oral plates and robust, angular adambulacrals.

Description. Disc of medium size; major radius $(R)$ $>37.4 \mathrm{~mm}$ (arm tips missing); minor radius $(r)$ $11.6 \mathrm{~mm} ; R / r=>3.2 / 1$; flat, stellate, arms long and pointed (although incompletely preserved), five in number; gradually tapering distally; interradii moderately narrow with rounded angles; superomarginals low, recumbent on abactinal surface, much wider than long interradially and along arm bases $(W / L$ ratio c. 3.6), more distally $W / L$ ratio decreases to 1.6; interradial superomarginals slightly cuneate; more distally, superomarginals almost meet adradially, being separated by a single row of rectangular abactinal ossicles; ornament of numerous ( $>80)$, close-set round granules, of comparable size along disc and arms; distal and proximal facets flat to slightly concave, bordered by well-developed articulation ridge, parallel to ossicle curvature and bordered by shallow groove. Number of superomarginals, counted from centre of interradius to arm tip (as preserved) $>15$.

Inferomarginals low, regularly curved on actinal surface, much wider than long interradially and along arm bases ( $W / L$ ratio $c$. 3.3), more distally $W / L$ ratio decreases to 1.25 and less; interradial inferomarginals clearly cuneate, equalling width of corresponding superomarginals; more distal inferomarginals longer than wide, their width equalling half (or less) of corresponding superomarginal width; ornament apparently less coarse than that of superomarginals, with comparable round granules.

Abactinal ossicles numerous, paxilliform, of more or less uniform size; ornament of few granules; madreporite not distinguished; a single row of rectangular abactinals extends to end of arm (not preserved).

Oral (actinal) surface collapsed; mouth central, small, defined by ten relatively large, prominent oral plates; no apical oral and suboral spines preserved; adambulacral ossicles robust, angular, no spines preserved.

Discussion. Although details of inferomarginal, oral and adambulacral granulation and spination cannot be assessed, the present specimen would appear to be close to the genus Paragonaster, although the rectangular abactinals of the single row that extends to the arm tip are longer than wide, rather than wider than long. For that reason, the new species is assigned to that genus with a query. Clark \& Downey (1992, pp. 255-7, pl. 62A-D) recorded two extant species of Paragonaster from the Atlantic, P. grandis H. L. Clark, 1941 and P. subtilis (Perrier, 1881). The former, known from relatively shallow waters $(257-540 \mathrm{~m})$ off Cuba and northern Brazil, has an $R / r$ ratio of 3.0/1 (i.e. close to the Carriacou form), but possesses more superomarginals and abactinal ossicles extend further into the arm base. In UF 114750, superomarginals at the arm base are first separated by a single row of rectangular abactinals from number 6; these are longer than wide. The second extant species, which occurs in deep-water settings (1845-4700 m) of the North American basin (off New York to Norfolk, Virginia), Gulf of Mexico, Azores and Rockall Trough to the Gulf of Guinea, has very long and attenuate arms and an $R / r$ ratio of 5.1/1. This, and the fact that it has more angular granules on inferomarginal ossicles and abactinals that are wider than long in the distal arm portion, differentiates it from P.(?) haldixoni sp. nov.

Remarks. Antillean fossil asteroids are known from six islands, ranging in age from Late Cretaceous to Pleistocene (Donovan, 2001; Donovan \& Schelfhorst, 2012), but only from disarticulated marginal plates that have not received adequate study. The two nominal fossil asteroid taxa from the region are from Cuba; these are the goniasterid Nymphaster miocenicus Valette, 1926, and the stauranderasterid Stauranderaster sanchezi Valette, 1926. These are either of Early Miocene (Valette, 1926, pp. 25, 26) or Early Eocene age (Sánchez Roig, 1949, pp. 294, 295). The poor line drawings of dissociated marginal ossicles that accompany the original descriptions show enough detail to confirm that they are utterly different from the new Carriacou species (Valette, 1926, pl. 1, figs 1, 2). Other published illustrations of marginal ossicles from the Middle Cenozoic of the region include the Lower Miocene (Donovan et al. 2005), and the Pliocene of 


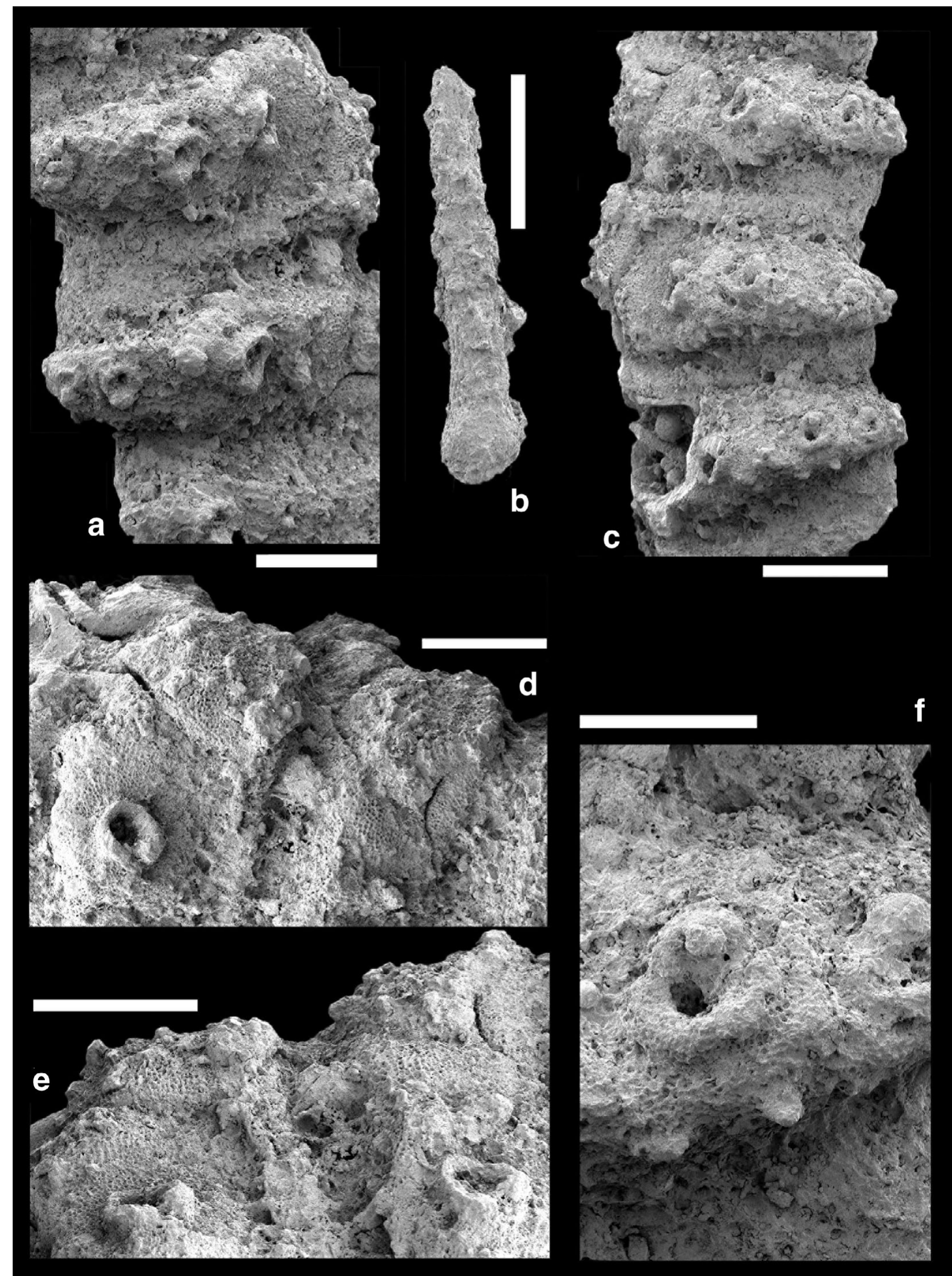

Figure 5. Ophiocamax ventosa sp. nov., NBC RGM 791 150, holotype, Middle Miocene starfish bed, Carriacou, The Grenadines. (a) Oblique lateral view of arm; (b) spine; (c) lateral view of arm. Scale bar represents $1.5 \mathrm{~mm}$. (d) Latero-dorsal view of arm; (e) latero-dorsal view of arm; (f) close-up of arm spine base. Scale bar represents $0.6 \mathrm{~mm}$. All scanning electron micrographs. Scale bars represent $1.2 \mathrm{~mm}$, unless stated otherwise. 


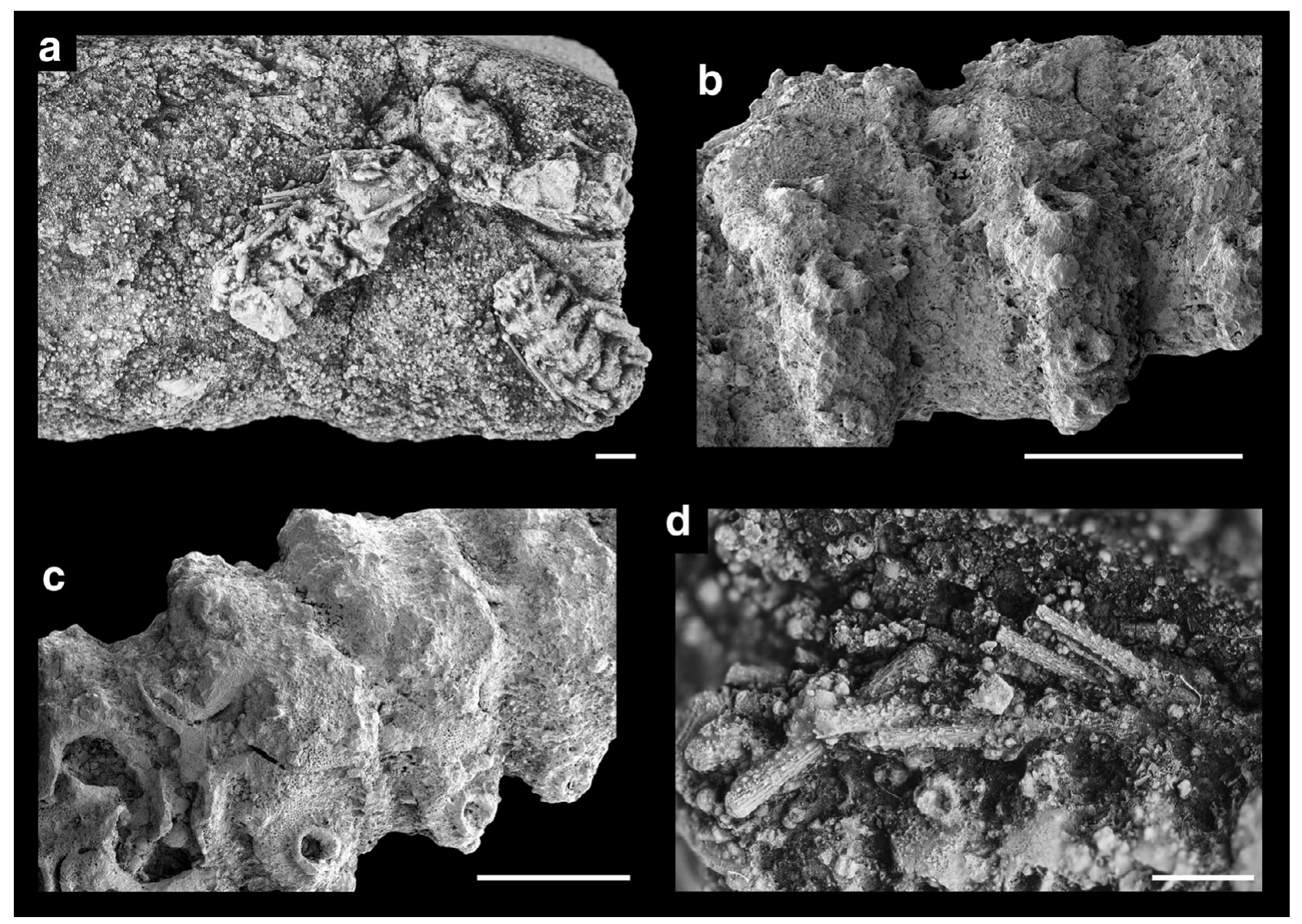

Figure 6. Ophiocamax ventosa sp. nov., NBC RGM 791 150, holotype. (a) Disc with proximal portions of arms in dorsal view; (b) proximal arm segments in lateral view; (c) proximal to median arm segments in dorsal view; (d) arm spines attached to proximal arm segments in dorsal view; note numerous planktonic foraminifera in matrix. Scale bars represent $2 \mathrm{~mm}$.

Jamaica and Curaçao (Donovan \& Paul, 1998; Donovan \& Schelfhorst, 2012); neither provides a convincing match.

Any environmental signal from this fossil is uncertain. Extant asteroids from the tropical western Atlantic occur at a multiplicity of water depths. The Grand Bay Formation, although undoubtedly deposited in deeper water, contains a range of benthic fossils and ichnofossils indicative of a range of palaeoenvironments, from terrestrial to deeper water (Donovan \& Harper, 1999; Donovan et al. 2003); such mixed assemblages are typical of oceanic islands with steep shelves (Donovan, 2002; Donovan et al. 2011). While it is tempting to suggest that the asteroids of this deposit were channel dwellers living in deep water that were overcome by a turbidity current, they may equally represent shallow-water taxa carried with the sediment mass flow into deeper water. However, the evidence provided by the associated deep-water ophiuroid Ophiocamax ventosa sp. nov. suggests that this is unlikely.

It is difficult to interpret the evolution of the Asteroidea within the Caribbean on the basis of the limited fossil evidence. The modern fauna is diverse. Hendler et al. (1995) recorded 13 asteroid species from shallow water $(30 \mathrm{~m}$ or less, that is, scuba depth), and Downey (1973) noted 95 species belonging to 56 genera from the Caribbean and Gulf of Mexico (see also Clark \& Downey, 1992). The Antillean fossil record is largely limited to disarticulated marginal ossicles; a single, nominal Miocene asteroid seemingly adds little to the picture. It has been suggested elsewhere that the 'modern' echinoid and (less confidently) crinoid faunas of the region mainly evolved from those taxa that survived the Eocene-Oligocene extinction events or migrated into the region soon afterwards (Dixon \& Donovan, 1994; Donovan, 2001). It is largely speculation at present to postulate a similar pattern in the Asteroidea.

Class OPHIUROIDEA Gray, 1840

Order OPHIURIDA Müller \& Troschel, 1840

Suborder OPHIURINA Müller \& Troschel, 1840

Family OPHIACANTHIDAE Ljungman, 1867

Genus Ophiocamax Müller \& Troschel, 1840

Type species. Ophiocamax vitrea Lyman, 1878, by original designation (see Spencer \& Wright, 1966).

Diagnosis. Ophiacanthid with large, stout radial shields and well-developed, small disc plates covered by thin skin; oral papillae spine-like and arranged in 
multiple rows; cluster of spine-like apical papillae; basal tentacle scales erect; dorsal and ventral arm plates commonly with thorns; arm spines long and thorny; second or third dorsal-most spine articulation often enlarged.

Range. Lower Miocene (Ishida, 2001) to Recent (Spencer \& Wright, 1966).

\section{Ophiocamax ventosa sp. nov.}

Figures 4-6

$2008 a$ ophiothricid(?) ophiuroid; Donovan et al. p. 52.

$2008 b$ ophiacanthid ophiuroid; Donovan et al. p. 18.

Etymology. From Latin, ventosus (-a), meaning 'windy,' but also 'fickle,' in reference to its geographic provenance and the alternation of spine articulations on lateral arm plates.

Holotype. A fragmentary disc and proximal portions of five arms, NBC RGM 791 150. The only specimen known.

Type locality and horizon. A channel-fill sandstone in the Grand Bay Formation (Middle Miocene) on the east coast of Carriacou, The Grenadines, Lesser Antilles. The locality is to the north of Tarleton Point in Jew Bay (Fig. 1), to the north of the stream and in the area of Jung (1971) localities 10706-10723 (GPS 12 29' 25" N, $61^{\circ} 25^{\prime} 30^{\prime \prime} \mathrm{W}$ ). The ophiuroid-bearing bed is exposed beneath the angular unconformity with the overlying Quaternary Carriacou root beds (see above).

Diagnosis. A species of Ophiocamax with large radial shields, equalling or exceeding half the disc diameter in length; proximal dorsal arm plates irregularly pentagonal, slightly wider than long, devoid of lateral wings and uniformly covered by coarse thorns; arm spines cylindrical with numerous small thorns, loosely arranged in irregular longitudinal rows.

Description. Disc fragmentary, exposing the dorsal side, reconstructed disc diameter c.17 mm; radial shields large, nearly triangular, slightly longer than half the disc diameter, contiguous; remaining dorsal disc plates poorly preserved; no disc spines or granules discernible; ventral side of disc unknown. Arms large (5.5 $\mathrm{mm}$ wide at base), preserving proximal and median portions; ventral arm plates not preserved; lateral arm plates strongly constricted, higher than wide in proximal segments, as high as wide in median ones; outer surface without conspicuous ornament or spurs on the proximal edge; up to five very large, earshaped to near-circular spine articulations with welldeveloped sigmoidal fold; size of spine articulations and gaps separating them strongly increasing in size dorsalwards; largest spine articulation dorsalmost on some segments, second or third dorsalmost on other segments, resulting in alternating pattern along the arm; spine articulations freestanding on broad, sharply elevated ridge in the middle of the distal half of the plate; dorsal spine articulations conspicuously facing dorsalwards or dorso-distalwards. Dorsal arm plates slightly wider than long in proximal segments, nearly as wide as long in median segments, irregularly pentagonal, with convex distal edge, straight proximalwards converging lateral edges and obtuse to nearly right proximal angle; entire outer surface of dorsal arm plates beset with scattered coarse, low thorns; dorsal arm plates in contact on all observable arm segments, separating dorsal tips of lateral arm plates. Arm spines very large, at least as long as three arm segments, cylindrical, finely reticulate with numerous small distalward-pointing thorns irregularly arranged in several longitudinal rows.

Remarks. The very large arm spines positioned on spine articulation with a well-developed sigmoidal fold clearly place this specimen in the family Ophiacanthidae. Within this family, large radial shields in combination with thorny arm spines and dorsal arm plates are typically found in the genus Ophiocamax. Detailed comparison of the morphology of lateral arm plates in extant ophiacanthids further suggests that nearly circular arm spine articulations positioned on a broad, sharply elevated ridge in the middle of the distal half of the plate, rather than at its distal edge, and an alternating pattern in the position of the largest spine articulation (varying between arm segments from dorsalmost to second or third dorsalmost), as observed in the above-described specimen, are exclusive features of Ophiocamax. Assignment to this extant genus is therefore warranted, although we could not confirm the presence of other diagnostic characters of this genus such as the cluster of apical papillae, the spine-like oral papillae arranged in multiple rows and the erect basal tentacle scales.

The genus Ophiocamax currently includes 11 accepted species (Stöhr \& O'Hara, unpub. data, http://www.marinespecies.org/ophiuroidea/). Among these, the Antarctic species Ophiocamax gigas Koehler, 1900, O. applicatus Koehler, 1922 and O. drygalskii Hertz, 1926, the North Atlantic O. patersoni Martynov \& Litvinova, 2008, the western Pacific O. nominata (Koehler, 1930), and O. brevicetra Baker, 1974, from off New Zealand differ from the Carriacou specimen in having considerably smaller radial shields. The Atlantic species O. dominans Koehler, 1906, and O. fasciculata Lyman, 1883, have smooth, triangular dorsal arm plates. Ophiocamax vitrea Lyman, 1878, differs in having much wider dorsal arm plates displaying lateral projections.

Similarities are greatest with $O$. hystrix Lyman, 1878, and O. austera Verrill, 1899, which are widespread 
in the Gulf of Mexico and, in the case of the former, in the Caribbean (Stöhr \& O'Hara, unpub. data, http://www.marinespecies.org/ophiuroidea/). Although $O$. austera and the Miocene Carriacou specimen share very similarly shaped dorsal arm plates, the former differs in having thorns restricted to the distal edge of, rather than covering, the entire surface of the dorsal arm plate. In addition, the arm spines of $O$. austera generally display very large thorns arranged in few regular longitudinal rows rather than a multitude of small thorns, loosely arranged in numerous rows. In $O$. hystrix, the dorsal arm plates display uniformly scattered thorns on their outer surface, as in the Miocene specimen, but the shape of the dorsal arm plates markedly differs. Thus, although rather limited, the morphological information extracted from the Carriacou specimen cannot be reconciled with the diagnoses of currently accepted species of Ophiocamax.

We therefore propose the new species $O$. ventosa sp. nov. for the Carriacou specimen. It is the first fossil species of Ophiocamax to be described formally. The genus has been previously recorded from the Lower Miocene of Aichi, Japan and the Upper Miocene of Yamagata, Japan (Ishida, 2001) which, along with the Caribbean record described here, implies that Ophiocamax had attained much of its present-day, nearcosmopolitan distribution by the Middle Miocene. The striking morphological similarities between $O$. ventosa sp. nov. and the two extant, tropical western Atlantic species, namely $O$. hystrix and $O$. austera, suggests that the former might be the ancestor of one, or even both, of the latter. We must however concede that the similarities only pertain to the morphological features exposed on the fossil specimen. Characters which could not be observed, in particular those of the mouth skeleton, could well challenge the strong similarities to the two above-mentioned extant species. The Carriacou material suggests that Ophiocamax has been a typical deep-sea group at least since the Miocene, and that the origin of the two extant tropical western Atlantic species, O. hystrix and O. austera (or at least of one of them), most probably lies in the Caribbean. In making the latter declaration the assumption is, of course, that the strong morphological similarity of these extant species to Miocene $O$. ventosa sp. nov. implies phylogenetic proximity.

There are some similarities with the Late Jurassic Ophiothrix(?) royeri (de Loriol, 1872) (Hess, 1960, pp. 396-401, figs 7, 8), known from articulated arm fragments and shown by Hess (1972) to be a junior synonym of Ophiurella bispinosa d'Orbigny, 1850. In fact, the Jurassic form displays a conspicuous alternating pattern in the position of the largest spine articulation. Here, however, the largest spine articulation is always the dorsalmost, the position of which varies between arm segments, from close to the remaining spine articulations to separated from the latter by a large gap. In $O$. ventosa sp. nov., in contrast, the largest spine articulation varies in position because it is the dorsalmost in some segments and the second or third dorsalmost in others. Similarities to the Jurassic form are therefore superficial at most.

\section{Discussion}

Although largely limited to active continental margins, outcrops of fossiliferous, Neogene, deep-water deposits are reasonably common, yet articulated deep-sea asterozoans are rare fossils. The potential of asteroids and ophiuroids to be fossilized as articulated skeletons largely depends on the occurrence of sediment mass transport events resulting in quick and effective burial of the skeletons. However, in deep-sea offshore settings, sedimentation rates are generally low and large-scale displacements of sediment masses are exceptional events usually bound to downslope gravity flows and turbidity currents (e.g. Menzies et al. 1973). It is therefore not surprising that articulated deep-sea asterozoan skeletons are even more rarely preserved than their shallow-water equivalents. As demonstrated by the Carriacou starfish bed, deeper-water deposits associated with islands in tectonically and volcanically active areas such as the Lesser Antilles hold the promise of further significant finds.

The discovery of these specimens suggests that rare, complete fossil specimens of other Caribbean echinoderm groups that are common at the present day, such as diadematoid echinoids (Donovan, 2005) and stalked crinoids (Donovan \& Veltkamp, 2001), may eventually be found; indeed, the first articulated ophiuroid from the Antilles was recently reported from Puerto Rico (Vélez-Juarbe \& Santos, 2008). Why no complete specimens of these taxa, otherwise only known from disarticulated ossicles, are known from the region remains uncertain. At least some of the deposits generated by mechanisms otherwise recognized as favourable to preservation, such as turbiditic (e.g. Pickerill et al. 1995) and pyroclastic deposits (e.g. T.A. Jackson, unpub. M.Sc. thesis, University of West Indies, 1970; Jackson, 1980), are locally common in the Antillean rock record; indeed, the Carriacou starfish bed is preserved in a turbidite derived from a volcanic source (Jackson et al. 2008). For comparison, there is a globally recognized paucity of articulated Cenozoic fossil crinoids (Hess, 1999). The only truly crinoid-rich deposits known from the Antilles underlies the Grand Bay Formation sensu stricto at Point Saint Hilaire (Donovan \& Veltkamp, 2001) (Fig. 1), yet the most complete specimens from these highly fossiliferous beds are rare short lengths of isocrinid pluricolumnals $(<10$ columnals). It is apparent that some taphonomic pathways in the Cenozoic of the tropical western Atlantic remain to be adequately explained.

The most abundant and best-studied Neogene occurrences of articulated deep-sea echinoderms have been reported from Japan (e.g. Oji, 2001; Ishida, 2001; Ishida et al. 2009). Our study adds another record to the extremely rare fossil occurrences of articulated 
deep-sea echinoderms. The latter are the most important and unambiguous source of evidence to assess the evolutionary history of modern and ancient deep-sea echinoderm lineages.

Acknowledgements. Support for fieldwork in Carriacou was provided by National Geographic Society grants 5722 96, 6625-99 and 8445-08, which are gratefully acknowledged. Additional support for fieldwork was provided by the McGinty Endowment of the Florida Museum of Natural History (to R.W.P.) and the National Sciences and Engineering Research Council of Canada (to R.K.P.). The late Dr Roy Blackman helped in the field during 2001. We thank S.L. Jakobsen (Statens Naturhistorisk Museum, Copenhagen, Denmark) and B.W.M. van Bakel (Oertijdmuseum De Groene Poort, Boxtel, the Netherlands) for preparation of the disc and proximal arm portions and photographs of the ophiuroid, respectively. We thank the Photographic Unit, The Natural History Museum, London, for preparing the images in Figure 3. Scanning electron micrographs of the ophiuroid were produced by S.S. at Stockholm; J.W.M.J. gratefully acknowledges the financial support through the European Commission's (FP 6) Integrated Infrastructure Initiative programme SYNTHESYS grant system (SE-TAF1530), which allowed him to work on extant ophiuroids at the Swedish Museum of Natural History, Stockholm (September 2006). This is University of Florida Contribution to Paleobiology 586. We thank Christopher R.C. Paul (University of Bristol) and a second, anonymous referee for their positive comments.

\section{References}

ARNOLD, B. W. \& CLARK, H. L. 1927. Jamaican fossil echini. Memoirs of the Museum of Comparative Zoology, Harvard 50, 1-75.

ARNOLD, B. W. \& ClARK, H. L. 1934. Some additional fossil echini from Jamaica. Memoirs of the Museum of Comparative Zoology, Harvard 54, 139-56.

AusicH, W. I. 2001. Echinoderm taphonomy. In Echinoderm Studies 6 (eds M. Jangoux \& J. M. Lawrence), pp. 171227. A.A. Balkema, Rotterdam.

BAKER, A. N. 1974. New species of brittle-stars from New Zealand (Echinodermata: Ophiuroidea). Records of the Dominion Museum 8, 247-66.

BERry, C. T. 1935. A Pliocene ophiuran from Trinidad. Journal of Paleontology 9, 430-33.

Blainville, H. M. D. DE. 1830. Dictionnaire des Sciences Naturelles. F. G. Levrault, Paris, 60 volumes text, 12 volumes plates, one volume portraits.

BLAKE, D. B. 1989. Asteroidea: functional morphology, classification and phylogeny. In Echinoderm Studies 3 (eds M. Jangoux \& J. M. Lawrence), pp. 179-223. A.A. Balkema, Rotterdam and Brookfield.

Blake, D. B. \& Portell, R.W. 2009. Implications for the study of fossil Asteroidea (Echinodermata) of new genera and species from the Eocene of Florida. Journal of Paleontology 83, 562-74.

BLAKE, D. B. \& PORTELL, R.W. 2011. Kionaster petersonae, n. gen. and sp. (Asteroidea), the first fossil occurrence of the Asterodiscididae, from the Miocene of Florida. Swiss Journal of Palaeontology 130, 25-42.

Clark, A. M. \& Downey, M. E. 1992. Starfishes of the Atlantic. Chapman and Hall, London, xxvi+794 pp.

CLARK, H. L. 1941. Reports on the scientific results of the Atlantis expeditions to the West Indies under the joint auspices of the University of Havana and Harvard
University. The echinoderms (other than holothurians). Memorias del Sociedad Cubana de Historia Natural 15, $1-154$.

Dixon, H. L. \& Donovan, S. K. 1994. Local extinction patterns and the decline of the Jamaican Paleogene echinoid fauna. Palaios 9, 506-11.

Dixon, H. L., Donovan, S. K. \& VeltKamp, C. J. 1994. Crinoid and ophiuroid ossicles from the Oligocene of Jamaica. Caribbean Journal of Science 30, 143-5.

DONOVAN, S. K. 1988. A preliminary biostratigraphy of the Jamaican fossil Echinoidea. In Echinoderm Biology: Proceedings of the Sixth International Echinoderm Conference, Victoria, British Columbia, 23-28 August, 1987 (eds R. D. Burke, P. V. Mladenov, P. Lambert \& R. L. Parsley), pp. 125-31. A.A. Balkema, Rotterdam.

Donovan, S. K. 1991. The taphonomy of echinoderms: calcareous multi-element skeletons in the marine environment. In The Processes of Fossilization (ed. S. K. Donovan), pp. 241-69. Belhaven Press, London.

Donovan, S. K. 1993. Jamaican Cenozoic Echinoidea. In Biostratigraphy of Jamaica (eds R. M. Wright \& E. Robinson), pp. 371-412. Geological Society of America Memoir 182, $\mathrm{x}+492 \mathrm{pp}$.

Donovan, S. K. 2001. Evolution of Caribbean echinoderms during the Cenozoic: moving towards a complete picture using all of the fossils. Palaeogeography, Palaeoclimatology, Palaeoecology 166, 177-92.

DONOVAN, S. K. 2002. Island shelves, downslope transport and shell assemblages. Lethaia 35, 277.

Donovan, S. K. 2005. The fossil record of Diadema in the Caribbean. Coral Reefs 24, 603-5.

Donovan, S. K., Gordon, C. M., VeltKamp, C. J. \& SCOTT, A. D. 1993. Crinoids, asteroids and ophiuroids in the Jamaican fossil record. In Biostratigraphy of Jamaica (eds R. M. Wright \& E. Robinson), pp. 125-30. Geological Society of America Memoir 182, x+492 pp.

DONOVAN, S. K. \& HARPER, D. A. T. 1999. A new paleobathymetric interpretation of the Middle Miocene Grand Bay Formation of Carriacou (Grenadines, Lesser Antilles). Ichnos 6, 283-8.

DONOVAN, S. K. \& HARPER, D. A. T. 2001. Brachio$\operatorname{pod} /$ crinoid associations in the late Cenozoic of the Antillean region. In Brachiopods: Past and Present (ed. C. H. C. Brunton, L. R. M. Cocks \& S. L. Long), pp. 268-74. Taylor and Francis, London.

Donovan, S. K., Harper, D. A. T., Portell, R. W., PICKERILl, R. K., JACKSON, T. A., JAGT, J. W. M. \& LiNDSAY, W. 2008a. Stars of the Caribbean Miocene: Grand Bay Formation, Carriacou, The Grenadines. The Palaeontological Association Newsletter 69 (Supplement), 51-2.

Donovan, S. K., Jackson, T. A., PORTEll, R. W., PICKERILL, R. K., HARPER, D. A. T. \& JAGT, J. W. M. 2008b. A starfish bed in the Lesser Antilles: Grand Bay Formation (Middle Miocene), Carriacou, The Grenadines. Abstracts, Foundations \& Directions: Celebrating Geography and Geology at the University of the West Indies, Kingston Jamaica, 7-11 July, 17-18.

Donovan, S. K. \& PAuL, C. R. C. 1998. Echinoderms of the Pliocene Bowden shell bed, southeast Jamaica. Contributions to Tertiary and Quaternary Geology 35, 129-46.

Donovan, S. K., Pickerill, R. K. \& Portell, R. W. 2002. A late Cenozoic 'root bed', an unconformity and the tectonic history of Carriacou, The Grenadines, Lesser Antilles. Proceedings of the Geologists' Association 113, 199-205. 
Donovan, S. K., Pickerill, R. K., Portell, R. W., JACKSON, T. A. \& HARPER, D. A. T. 2003. Miocene palaeobathymetry and palaeoenvironments of Carriacou, the Grenadines, Lesser Antilles. Lethaia 36, 255-72.

Donovan, S. K., Portell, R. W. \& VeltKamp, C. J. 2005. Lower Miocene echinoderms of Jamaica, West Indies. Scripta Geologica 129, 91-135.

Donovan, S. K., Portell, R. W. \& WAVERen, I. M. VAN. 2011. Island slopes and jumbled shell beds. Scripta Geologica 142, 17-18.

Donovan, S. K. \& Schelfhorst, R. 2012. A Pliocene asteroid from the Netherlands Antilles. Bulletin of the Mizunami Fossil Museum 38, 75-7.

Donovan, S. K. \& VeltKamp, C. J. 2001. The Antillean Tertiary crinoid fauna. Journal of Paleontology 75, 72131.

DownEY, M. E. 1973. Starfishes from the Caribbean and the Gulf of Mexico. Smithsonian Contributions to Zoology 126, vi+158 pp.

FISHER, W. K. 1919. Starfishes of the Philippine seas and adjacent waters. Bulletin of the United States National Museum 3(100), 1-547.

FORBES, E. 1841. A History of British Starfish and Other Animals of the Class Echinodermata. John Van Voorst, London, $267 \mathrm{pp}$.

GALE, A. S. 1987. Phylogeny and classification of the Asteroidea (Echinodermata). Zoological Journal of the Linnean Society 89, 107-32.

GRAY, J. E. 1840. A synopsis of the genera and species of the Class Hypostoma (Asterias Linne). Annals and Magazine of Natural History (1)6, 175-84, 275-90.

HARPER, D. A. T. \& PICKERILL, R. K. 2008. Generation of brachiopod-dominated shell beds in the Miocene rocks of Carriacou, Lesser Antilles. Geological Journal 43, 573-81.

HAWKINS, H. L. 1923. Some Cretaceous Echinoidea from Jamaica. Geological Magazine 60, 199-216.

HAWKINS, H. L. 1924. Notes on a new collection of fossil Echinoidea from Jamaica. Geological Magazine 61, 312-24.

HaWkins, H. L. 1927. Descriptions of new species of Cainozoic Echinoidea from Jamaica. Memoirs of the Museum of Comparative Zoology, Harvard 50, 7684.

Hawkins, H. L. 1930. In C. T. TrechmanN, The Manchioneal Beds of Jamaica, pp. 215-16. Geological Magazine 78, 199-218.

Hendler, G., Miller, J. E., Pawson, D. L. \& Kier, P. M. 1995. Sea Stars, Sea Urchins, and Allies: Echinoderms of Florida and the Caribbean. Smithsonian Institution Press, Washington, DC, xi+390 pp.

Hertz, M. 1926. Die Ophiuroiden der Deutschen SüdpolarExpedition 1901-1903. Deutsche Südpolar-Expedition 1901-1903 im Auftrage des Reichsministeriums des Inneren herausgegeben von Erich von Drygalski, 19. Zoologie 11, 1-54+ii. Walter De Gryter Inc., Berlin.

Hess, H. 1960. Ophiurenreste aus dem Malm des Schweizer Juras und des Departements Haut-Rhin. Eclogae geologicae Helvetiae 53, 385-421.

HESS, H. 1972. Eine Echinodermen-Fauna aus dem mittleren Dogger des Aargauer Juras. Schweizerische Paläontologische Abhandlungen 92, 1-87.

Hess, H. 1999. Tertiary. In Fossil Crinoids (eds Hess, H., Ausich, W. I., Brett, C. E. \& Simms, M. J.), pp. 233-6. Cambridge University Press, Cambridge, $x v+275$ pp.

ISHIDA, Y. 2001. Cenozoic ophiuroids from Japan; particularly those conspecific with extant species. In
Echinoderm Research 2001 (eds J.-P. Féral \& B. David), pp. 53-9. Swets \& Zeitlinger, Lisse.

ISHIDA, Y., KOIKE, H. \& NARITA, K. 2009. Ophiacantha (Echinodermata, Ophiuroidea) from the middle Miocene Bessho Formation at Azumino City, Nagano Prefecture, central Japan. Research Report of the Shinshushinmachi Fossil Museum 12, 1-6.

JACKSON, T. A. 1980. The composition and differentiation of the volcanic rocks of Carriacou, the Grenadines, West Indies. Bulletin Volcanologique 43, 311-24.

Jackson, T. A., Scott, P. W., Donovan, S. K., Pickerill, R. K., Portell, R. W. \& Harper, D. A. T. 2008. The volcaniclastic turbidites of the Grand Bay Formation, Carriacou, Grenadines, Lesser Antilles. Caribbean Journal of Science 44, 116-24.

JoNeS, D. S. \& PORTELL, R. W. 1988. Occurrence and biogeographic significance of Heliaster (Echinodermata: Asteroidea) from the Pliocene of southwest Florida. Journal of Paleontology 62, 126-32.

JUNG, P. 1971. Fossil mollusks from Carriacou, West Indies. Bulletins of American Paleontology 61 (269), 147-262.

KOEHLER, R. 1900. Note préliminaire sur les Ėchinides et les Ophiures de l'Expédition Antarctique Belge. Bulletin de l'Académie Royale de Belgique 11, 814-20.

KoeHLeR, R. 1906. Ophiures. Expéditions Scientifiques du Travailleur et du Talisman 8, 245-311.

KoEHLER, R. 1922. Echinodermata: Ophiuroidea. Australasian Antarctic Expedition 1911-1914. Scientific Report Series C 8, 5-98. Government Printing Office, Sydney.

KoEHLER, R. 1930. Ophiures recueillies par le Docteur Th. Mortensen dans les Mers d'Australie et dans l'Archipel Malais. Papers from Dr Th. Mortensen's Pacific Expedition 1914-16. LIV. Videnskabelige Meddelelser fra Dansk naturhistorisk Forening 89, 1-295.

LJUNGMAN, A. V. 1867. Ophiuroidea viventia huc usque cognita enumerat. Ofversigt af Kongliga VetenskapAkademiens Förhandlingar Stockholm 1866, 303-36.

LORIOL, P. DE. 1872. Description géologique et paléontologique des étages jurassiques supérieurs de la HauteMarne. Mémoires de la Société linnéenne de Normandie 16, $1-542$.

LYMAN, T. 1878. Ophiurans. Reports on the dredging operations of the US coast survey Str. "Blake". Bulletin of the Museum of Comparative Zoology 5, 217-38.

LYMAN, T. 1883. Reports on the results of dredging, under the supervision of Alexander Agassiz, in the Carribbean Sea (1878-79), and on the east coast of the United States, during the summer of 1880 , by the U.S. coast survey steamer "Blake", commander J.R. Bartlett, U.S.N., commanding. XX. Report on the Ophiuroidea. Bulletin of the Museum of Comparative Zoology at Harvard College 10, 227-87.

Martynov, A.V. \& Litvinova, N.M. 2008. Deep-water Ophiuroidea of the northern Atlantic with descriptions of three new species and taxonomic remarks on certain genera and species. Marine Biology Research 4, 76-111.

MENZIES, R. J., GEORGE, R.Y. \& Rowe, G.T. 1973. Abyssal Environment and Ecology of the World Oceans. WileyInterscience, New York, $488 \mathrm{pp}$.

MÜller, J. \& TROSCHEL, F. H. 1840. System der Asteriden. Friedrich Vieweg und Sohn, Braunschweig, $\mathrm{xx}+134 \mathrm{pp}$.

OJI, T. 2001 Deep-sea communities. In Palaeobiology II (eds D. E. G. Briggs \& P. R. Crowther), pp. 444-7. Blackwell Science, Oxford.

Orbigny, A. D. D'. 1850. Prodrome du Paléontologie Stratigraphique Universelle des Animaux Mollusques et Rayonnés Faisant suite au cours Élémentaire de 
Paléontologie et de Géologie Stratigraphique. 2, Masson, Paris, $428 \mathrm{pp}$.

Oyen, C. W. \& PORTELL, R. W. 2001. Diversity patterns and biostratigraphy of Cenozoic echinoderms from Florida. Palaeogeography, Palaeoclimatology, Palaeoecology 166, 193-218.

PERRIER, E. 1881. Description sommaire des espèces nouvelles d'Astéries. Bulletin of the Museum of Comparative Zoology at Harvard University 9, 1-31.

PERRIER, E. 1884. Mémoire sur les étoiles de mer recueillis dans la Mer des Antilles et la Golfe de Mexique. Nouvelles Archives du Muséum National d'Histoire Naturelle de Paris 6, 127-276.

Pickerill, R. K., Donovan, S. K. \& DunN, J.T. 1995. Enigmatic cobbles and boulders in the Paleogene Richmond Formation of eastern Jamaica. Caribbean Journal of Science 31, 185-99.

SÁnCHEZ RoIG, M. 1949. Contribución a la paleontología Cubana. Los equinodermos fósiles de Cuba. Paleontologia Cubana 1, 1-302.

SLADEN, W.P. 1885. Asteroidea. In Report on the Scientific Results of the Voyage of the Challenger, Narrative 1(2) (eds C. Wyville Thomson \& J. Murray), 607-17. Her Majesty's Stationary Office, London.

SLADEN, W.P. 1889. The Asteroidea. Report on the Scientific Results of the Voyage of the Challenger, Zoology 30, $1-935$.
Speed, R. C., Smith-Horowitz, P. L., Perch-Nielsen, K V. S., SAunders, J. B. \& SANFILIPPO, A. B. 1993. Southern Lesser Antilles Arc Platform: pre-late Miocene stratigraphy, structure, and tectonic evolution. Geological Society of America Special Paper 277, $98 \mathrm{pp}$.

SPencer, W. K. \& Wright, C. W. 1966. Asterozoans. In Treatise on Invertebrate Paleontology, Part $U$, Echinodermata 3(1) (ed. R. C. Moore), U4-U107. New York and Lawrence: The Geological Society of America and The University of Kansas Press.

ThUY, B. \& STÖHR, S. 2011. Lateral arm plate morphology in brittle stars (Echinodermata: Ophiuroidea): new perspectives for ophiuroid micropalaeontology and classification. Zootaxa 3013, 1-47.

VAlETTE, A. 1926. Nota sobre dos asteroideos nuevos de la isla de Cuba. 23-26. In Contribución a la paleontología Cubana. Los equinodermos fósiles de Cuba (M. Sánchez Roig). Boletin de Minas 10, 179+v pp.

VÉLEZ-JUARBE, J. \& SANTOS, H. 2008. Fossil Echinodermata from Puerto Rico. In Echinoderm Paleobiology (eds W. I. Ausich \& G. D. Webster), 368-95. Indiana University Press, Bloomington.

VERRILL, A.E. 1899. Report on the Ophiuroidea collected by the Bahama expedition in 1893. Bulletin from the Laboratories of Natural History of the State University of Iowa 5, 1-86. 